КРАШЕНІНІН О.С., доктор технічних наук, професор кафедри експлуатації та ремонту рухомого складу,

ЯКОВЛЕВ С. С., аспірант кафедри експлуатації та ремонту рухомого складу, ШАПАТІНА О.О., кандидат технічних наук, старший викладач кафедри управління вантажною і комерційною роботою

(Український державний університет залізничного транспорту)

\title{
Обгрунтування стратегії організації технічного обслуговування, поточного ремонту швидкісного рухомого складу в умовах України
}

Експлуатація закордонного чивикісного рухомого складу (ШРС), у тому числі електропоїздів, для організачї̈ швидкісних залізничних пасажирських перевезень потребує обтрунтування стратегії їх утримання.

У статті розглядаються питання оцінки чинників, які впливають на обсяг витрат, пов'язаних з утриманням ШРС, техніко-економічної оичінки ичих витрат для трьох можливих стратегій організації їх утримання. На основі такого підходу сформована графічна залежність добутків $і$ витрат на організацію утримання цзього РС з урахуванням запровадження відповідних стратегій.

Ключові слова: швидкісний рухомий склад, стратегія технічного обслуговування (ТО), поточного ремонту (ПР).

\begin{abstract}
Постановка проблеми
АТ «Укрзалізниця» отримала на свій баланс кілька одиниць електричного РС, який забезпечує швидкість руху на деяких дільницях від 140 до 160 км/год. Умовно його називають швидкісним рухомим складом (ШРС), що не відповідає загальній класифікації ШРС і високошвидкісного рухомого складу (ВШРС) [2, 3]. Але це не головне, оскільки закордонний РС суттєво відрізняється від вітчизняного. Це стосується як особливостей конструкції, так і системи утримання, тобто організації ТО, ПР і КР та термінів його експлуатації. Наприклад, електропоїзди HRCS2, виробництва південнокорейської компанії Hyundai Rotem, були придбані у 2012 році і для них жодного разу не виконувались великі ремонти через відсутність необхідних потужностей. А електропоїзди ЕJ 675, чеського виробника Škoda Holding (Škoda Transportation), що поставлені в Україну, вже були в експлуатації на залізницях Чехії, мали налагоджену систему ТО, ПР і КР 3 урахуванням вимог щодо виконання обсягів робіт і середньодобового пробігу. В умовах України ці вимоги до ШРС ЕЈ 675 не завжди виконувались, що призвело до вимушеної передислокації регіонів експлуатації і організації іx утримання. Вітчизняний електропоїзд ЕКр1 «Тарпан», виробництва Крюківського вагонобудівного заводу, поки не може повноцінно конкурувати з закордонним рухомим складом і не завжди з об’єктивних причин.
\end{abstract}

() О. С. Крашенінін, С. С. Яковлев, О. О. Шапатіна, 2021
Таке різноманіття ШРС, що експлуатується на АТ «Укрзалізниця», потребує прийняття нетривіальних $\mathrm{i}$ зважених рішень щодо стратегії утримання цього ШРС. У такій постановці питання, що розглядаються в статті, мають актуальний характер.

\section{Аналіз останніх досліджень і публікацій}

Як окрема задача, завдання обгрунтування системи TO, ПР ШРС у нашій країні комплексно не вирішувалося.

Концептуальні питання i завдання розвитку залізничного транспорту поставлені в розпорядженні Кабінету Міністрів України № 979-р від 31.12.2004 року, яким було схвалено Концепцію Державної цільової програми впровадження на залізницях швидкісного руху пасажирських поїздів на 2005-2015 роки [1].

Окремим питанням запровадження системи ПО, ПР ШРС в Україні присвячені роботи [4-6], в яких розглядалися питання адаптації ремонтної бази депо до обслуговування РС інших депо; оцінка потужностей ремонтної інфраструктури депо для закріплення за ними регіональних сервісних центрів 3 обслуговування ШРС; обгрунтування величини запасів для ремонтних підрозділів.

У роботі [7] проведено оцінку конкурентоспроможності ШРС різних постачальників.

Загальним питанням 3 оптимізації системи утримання ТРС у нашій країні присвячено роботи [8-10]. 
У них розглядалися окремі завдання визначення балансу витрат на ТО, ПР ТРС i забезпечення надійності ТРС, запровадження в ремонт прогресивних технологій на базі механізації i автоматизації, технології випробувань і діагностування обладнання ТРС, оптимізації витрат за життєвий цикл експлуатації TPC.

Ці підходи $\epsilon$ основою розробки стратегії утримання закордонного ШРС i ТРC, що експлуатується на АТ «Укрзалізниця».

Мета дослідження полягає в обгрунтуванні стратегії організації ТО, ПР ШРС в умовах України з урахуванням техніко-економічних аспектів варіантів цієї організації.

Для цього поставлено такі завдання:

1. Визначити чинники, які впливають на ефективність стратегії організації ТО, ПР ШРС.

2. Розробити модель для оцінки різних варіантів стратегії організації ТО, ПР ШРС.

3. Отримати результати моделювання.

\section{Виклад основного матеріалу дослідження}

Організація ТО, ПР ТРС передбачає комплексне узгодження стратегії і тактики, тобто циклічності, періодичності і обсягів робіт на кожному конкретному виді ТО і ПР, 3 урахуванням розвинутої інфраструктури ремонту.

Крім цього, потрібне зважене рішення щодо організації системи утримання ТРС. Для нашої країни багато років була основною планово-попереджувальна система ремонту, яка поступово удосконалювалася запровадженням засобів ремонту і діагностування.

Після надходження на залізниці технічний стан ТРС повністю забезпечувався проведенням відновлювальних заходів на ТО, ПР, а при досягненні нормативних термінів КР ТРС направлявся для проведення капітальних ремонтів різних видів на локомотиворемонтні заводи.

На початку експлуатації закордонного ШРС чинна інфраструктура не могла бути напряму задіяна в процес утримання цього РС, що пов'язано 3 непристосованістю ремонтного господарства до проведення складних заходів 3 обслуговування i ремонту, насамперед наукоємного обладнання. Закріплення ШРС за окремими депо передбачало умову, що ці депо здатні виконувати заходи щодо забезпечення безпеки експлуатації цього ШРС i підтримування його технічного стану на базі діючого ремонтного виробництва.

Як показав досвід деяких депо, в рамках існуючого ремонтного обладнання i засобів діагностування можлива достатньо якісна організація виконання ТО, ПР для ШРС на основі рекомендованих технологій постачальників.
Але, 3 іншого боку, це показало, що для проведення великих видів ремонтів потрібно визначитися у таких питаннях:

- модернізувати ремонтну базу підприємств (локомотивних депо) для можливості проведення усіх видів ТО, ПР для ШРС (стратегія 1);

- створювати окремі підприємства без залучення існуючої ремонтної інфраструктури для забезпечення ТО, ПР ШРС на рівні деякого регіону експлуатації цих ШРС (стратегія 2);

- експлуатувати поставлений ШРС без проведення великих видів ПР, а їх виконання покласти на постачальників на заводах-виробниках (стратегія 3).

Відкидаючи політичні аспекти, що існують у деяких керівних структурах, зупинимося на технікоексплуатаційному аспекті завдання.

Нехай на залізниці експлуатується ШРС кількістю $N_{e}$ одиниць (експлуатаційний парк). Ціна однієї одиниці ШРС складає $\bigsqcup_{\text {ШРС }}$. Загальний добуток від експлуатації ШРС незалежно від прийнятої стратегії приймаємо однаковими:

$Д=f\left(d, N_{e}, T_{H}\right)$

де $d-$ добуток від експлуатації однієї одиниці ШРС;

$N_{e}$ - експлуатаційний парк ШРС;

$T_{H}$ - нормативний термін експлуатації ШРС.

Добуток $d$ можна оцінити таким чином:

$d=C \times S_{i}$

де $C$ - тарифна ставка на надання послуг 3 перевезень, грн/пас.км;

$S_{i}$ - обсяг перевізної роботи за різних стратегій, пас.км.

Витрати на придбання та експлуатацію ШРС містять: сумарну ціну закупівлі ШРС; витрати енергоресурсів на перевізний процес; витрати на ремонт, амортизацію, заробітну плату, накладні витрати тощо.

Будемо вважати, що динаміка цих витрат незалежно від обраної стратегії ШРС однакова.

При виборі стратегії 1 первинні витрати

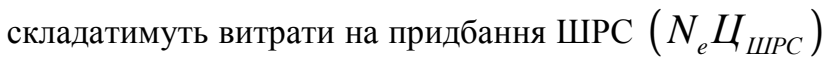
i модернізацію ремонтної інфраструктури, яку приймемо умовно на рівні $0,2 N_{e} Ц_{\text {ШРС }}$. 
При запровадженні стратегії 2 первинні витрати складатимуть, як і раніше, витрати на придбання ШРС i, на відміну від стратегії 1 , на будівництво спеціалізованого підприємства, витрати на яке оптимістично приймемо на рівні $(0,5 \div 0,7) N_{e} U_{\text {ШРC }}$

При реалізації стратегії 3 модернізація існуючих і будівництво нових підприємств не потрібні, але при організації великих ПР та КР різних обсягів ШРС відправляються на ремонтну базу постачальників ШРС. Витрати на ці заходи перевищують витрати на КР на місці експлуатації ШРС. За приблизною оцінкою витрати на КР складають до $0,8 Ц_{\text {ШРC }}$ одного ШРС. За період експлуатації для ШРС, як і для іншого ТРС, передбачено два КР-1 і один КР-2. А 3 урахуванням витрат на перевезення ШРС на ремонтну базу постачальника витрати на всі КР складатимуть фактично три ціни ШРС.

Оскільки фактичні дані для точного розрахунку технічно-економічної оцінки ефективності різних стратегій недостатні, зобразимо якісну динаміку добутків і витрат у вигляді графічної залежності (рис. 1).

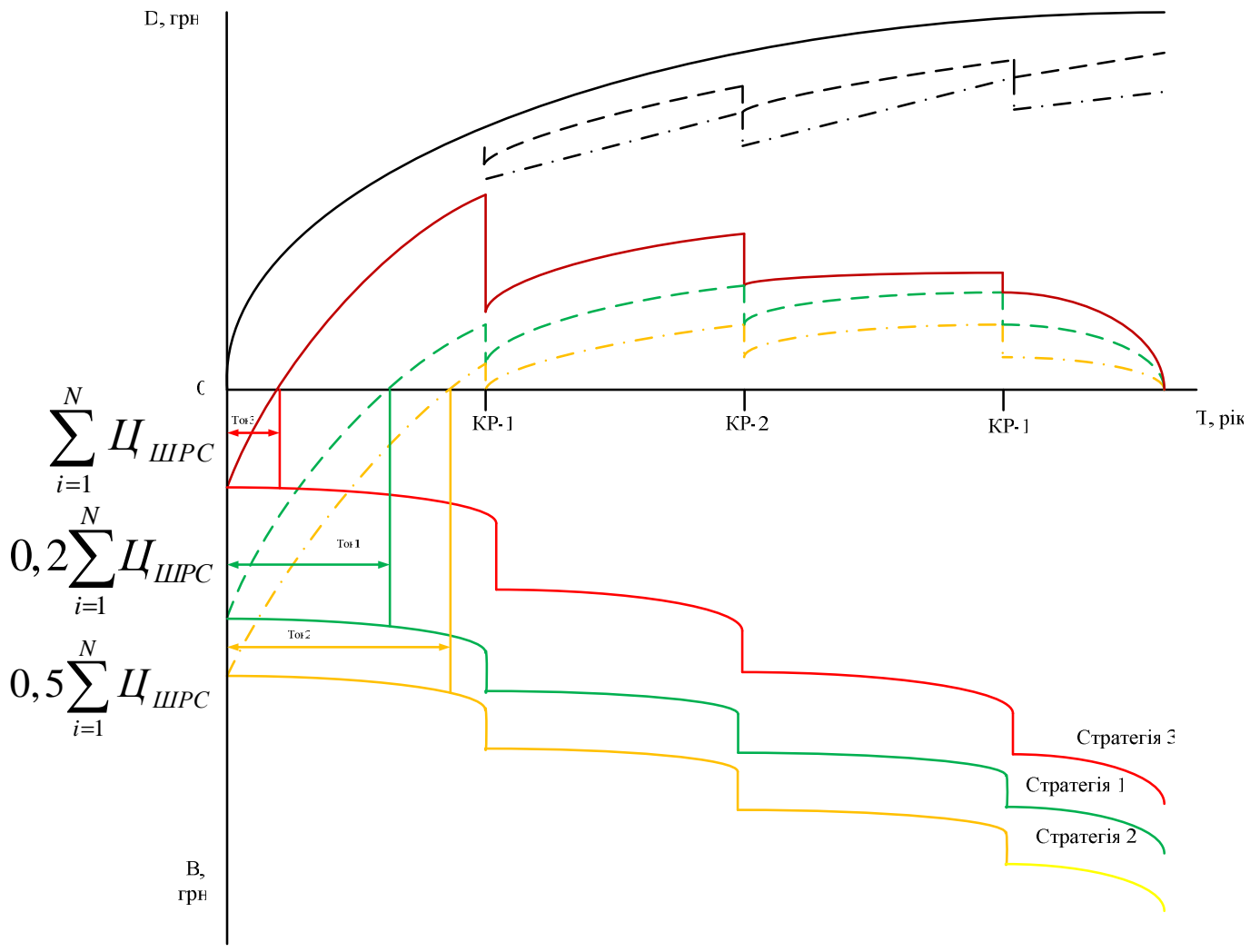

Рис. 1. Динаміка зміни добутку і витрат від експлуатації ШРС за різними стратегіями

Як бачимо $з$ наведеної залежності, на перший погляд, стратегія 3 найпривабливіша, але це можливо лише за умови незмінної тенденції прийнятого припущення щодо динаміки добутку. Насправді, коли будуть організовані КР для частини експлуатаційного парку ШРС, ця залежність «просяде» на більшу величину, ніж для стратегій 1 i 2 (показано зеленим і помаранчевим кольором), оскільки на деякий період буде потрібно відкоригувати розклад руху ШРС, що знизить сумарну дохідність від їх експлуатації.
Для стратегії 1 зменшення дохідності на величину зменшення обсягу перевезень $S_{1}$ нижче, оскільки відремонтовані на КР ШРС швидше надійдуть до експлуатації:

$$
S_{1}=\left(N_{e}-N_{e K P-1}\right) C_{\partial о \sigma} \Pi\left(N_{e}\right) T_{e \kappa},
$$

де $N_{e \kappa P-1}-$ кількість ШРС, для яких виконується капітальний ремонт; 


$$
\begin{aligned}
& \Pi\left(N_{e}\right) \text { - кількість перевезених пасажирів; } \\
& C_{\text {доб }}-\text { середньодобовий пробіг, км/доба; } \\
& T_{e \kappa}-\text { термін експлуатації до проведення }
\end{aligned}
$$
відповідного КР, діб.

Тобто приведений прибуток дещо скорочується в більшу сторону відносно стратегії 3 .

Аналогічно і для стратегії 2 техніко-економічні показники по відношенню до стратегії 3 дещо поліпшуються.

\section{Висновки 3 дослідження і перспективи подальшого розвитку у цьому напрямку}

За результатами дослідження отримано такі висновки:

1. Визначено основні чинники, що впливають на ефективність стратегії організації ТО, ПР ШРС, а саме різницю між добутками і витратами.

2. Розроблено техніко-економічну модель визначення ефективності використання ШРС для різних стратегій його утримання, яка реалізована у графічному вигляді.

3. Показано, що стратегія 1 (модернізація ремонтної бази) найбільш перспективна, оскільки значно скорочує витрати на адаптацію ремонтної інфраструктури до організації ТО, ПР ШРС. Разом 3 цим стратегія 2 при розвитку вітчизняного локомотивобудування i запровадження сервісу має стати основою системи утримання ШРС. Крім того, можливе і тісне співробітництво депо 3 вітчизняними заводами 3 виробництва ШРС, що значно скоротить витрати на організацію КР.

\section{Список використаних джерел}

1 Про схвалення Концепції Державної цільової програми впровадження на залізницях швидкісного руху пасажирських поїздів на 20052015 роки: розпорядження Кабінету Міністрів України від 31 грудня 2004 р. № 979-р. URL: http://zakon3.rada.gov.ua/laws/show/979-2004$\% \mathrm{D} 1 \% 80$

2 Высокоскоростной железнодорожный транспорт. Общий курс: учеб. пособие: в 2 т. / И. П. Киселёв и др.; под ред. И. П. Киселёва. Москва: ФГБУ ДПО «Учебно-методический центр по образованию на железнодорожном транспорте», 2018. 428 с.

3 Теорія та конструкція рухомого складу високошвидкісного транспорту : підручник / С. В. Панченко, О. Б. Бабанін, А. О. Каграманян, Ю. М. Дацун. Харків: УкрДУЗТ, 2018. 362 с.

4 Яковлев С. С. Забезпечення технологічної надійності роботи підрозділів ремонтного господарства локомотивного депо. Інформаційно- керуючі системи на залізничному транспорті. Харків: УкрДУЗТ, 2019. № 4. С. 27-39.

5 Територіальне закріплення локомотивних депо за сервісними центрами / О.С. Крашенінін, С. С. Яковлев, О. О. Шапатіна, О. О. Турубара. Інформачійно-керуючі системи на залізничному mранспорті. Харків: УкрДУЗТ, 2018. № 5. C. $10-22$.

6 Крашенінін О.С., Пономаренко О. В., Яковлев С. С. Забезпечення ремонтного господарства депо оптимальним розміром запасів. Вісник Східноукраӥнського національного університету імені Володимира Даля. Сєвєродонецьк, 2017. № 3. С. 95-100.

7 Крашенінін О.С., Яковлев С. С. Оцінка конкурентоспроможності швидкісного рухомого складу українського виробництва. 3б. наук. пращь УкрДУЗТ. Харків, 2017. № 174. С. 96-105.

8 Методы оценки жизненного цикла тягового подвижного состава железных дорог: монографія / Э. Д. Тартаковский, С. Г. Грищенко, Ю. Е. Калабухин и др. Луганск: «Ноулидж», 2011. $174 \mathrm{c}$.

9 Оцінка показників ТО при подовженні терміну експлуатації ТРС по наробці / Е. Д. Тартаковський, О. В. Устенко, О. С. Крашенінін та ін. 3б. наук. праць УкрДАЗТ. Харків: УкрДАЗТ, 2012. Вип. 132. C. 5-11.

10 Четвергов В. А., Киселёв В. И., Данковцев В. Т. Техническое обслуживание и ремонт локомотивов. Москва: Учебно-методический центр по образованию на железнодорожном транспорте, 2007. $558 \mathrm{c}$.

11 Tartakovsky E., Ustenko O., Puzyr V., Datsun Y. System approach to the organization of locomotive maintenance on Ukraine railways. Studies in Systems Decision and Control. Ukrainian state university of railway transport. 2017. № 87. P. 217-236.

12 V. Puzyr, Y. Datsun, O. Obozny. Design of algorithm for identification of locomotive electrical machine unit during repair. International Journal of Engineering \& Technolog. Vol 7, No 4.3 (2018): Special Issue 3, P. 157-161.

URL: https://www.sciencepubco.com/index.php/ijet/article/v iew/19727/9154

Krasheninin O., Yakovlev S., Shapatina O. Rationale of the strategy of organization of technical maintenance of ordinary repairing of high-speed rolling stock in the conditions of Ukraine.

Abstract. The Article considers the issues of estimating the factors affecting the amount of costs associated with the maintenance of HSRS, technical and economic evaluation of these costs for the three possible strategies for their maintenance management. Based on such approach, the graphic dependence of incomes and 
expenses to manage this RS maintenance has been formed taking into account introduction of the corresponding strategies. HRCS2 electric trains manufactured by Hyundai Rotem, the South Korean company, were purchased by Ukrzaliznytsia JSC in 2012 and have never undergone major repairs due to a lack of required capacities. And EJ 675 electric trains, by Škoda Holding (Škoda Transportation), the Czech manufacturer, delivered to Ukraine, have already been in operation on the railways of the Czech Republic, had a well-established system of maintenance support, regular and general maintenance taking into account the requirements for workload and average daily run time. In Ukraine conditions, these requirements for EJ 675 HSRS were not always met which forced to redeploy regions of operation and manage their maintenance in the deployment initial version. The Tarpan EKr1 domestic electric train manufactured by the Kriukiv Railway Car-Building Plant cannot yet fully compete with foreign rolling stock, and not always for objective reasons.

Such a variety of HSRS operated by Ukrzaliznytsia JSC requires non-trivial and considered decisions on the strategy of maintaining this HSRS. In such a statement, the issues considered in the Article are relevant.

Keywords: high-speed rolling stock, maintenance strategy, regular maintenance strategy, costs, incomes.

Надійшла 08.06.2021 p.
Krasheninin Alexander Semenovich, Doctor of Technical Sciences, Professor, Department of Operation and Repair of Rolling Stock, Ukrainian State University of Railway Transport, Kharkiv, Ukraine. E-mail: errs1@mail.ua https://orcid.org/0000-0001-7462-3372

Yakovlev Sergey Sergeevich, post-graduate student of the Department of Operation and Repair of Rolling Stock, Ukrainian State University of Railway Transport, Kharkiv, Ukraine. E-mail: errs1@mail.ua. https://orcid.org/00000002-8578-4566

Shapatina Olha Oleksandrivna, PhD in Sci. Eng., Senior Lecturer of cargo and commercial work department, Ukrainian State University of Railway Transport, Kharkiv, Ukraine. E-mail: uvkr@kart.edu.ua. https://orcid.org/0000-0002-9185-6212
Крашенінін Олександр Семенович, доктор технічних наук, професор кафедри експлуатації та ремонту рухомого складу Украӥнського державного університету залізничного транспорту, Харків, Україна. E-mail: errs1@mail.ua. https://orcid.org/00000001-7462-3372

Яковлев Сергій Сергійович, аспірант кафедри експлуатації та ремонту рухомого складу Українського державного університету залізничного транспорту, Харків, Україна. E-mail: errs1@mail.uа. https://orcid.org/0000-0002-8578-4566

Шапатіна Ольга Олександрівна, кандидат технічних наук, старший викладач кафедри управління вантажною $i$ комериійною роботою Украӥнського державного університету залізничного транспорту, Харків, Україна. E-mail: uvkr@kart.edu.ua https://orcid.org/0000-0002-9185-6212 